\title{
DEIKSIS PERSONA DALAM BAHASA MUNA
}

\author{
Bella Fatahu Rahmah ${ }^{1}$, Zalili Sailan ${ }^{2}$ dan Erny Harijaty ${ }^{3}$ \\ pbsi.fkip.uho@gmail.com \\ 1,2,3, Jurusan Pendidikan Bahasa dan Sastra Indonesia, \\ Fakultas Keguruan dan Ilmu Pendidikan, Universitas Halu Oleo \\ Kampus Hijau Bumi Tridharma Anduonohu, Kendari, Indonesia
}

\begin{abstract}
ABSTRAK
Tujuan dalam penelitian ini adalah untuk mendeskripsikan bentuk dan makna kata deiksis persona dalam bahasa Muna. Jenis penelitian ini yaitu desktiptif kualitatif, penelitian kualitatif selalu bersifat deskriptif , artinya data yang dianalisis dan hasil analisisnya berbentuk deskriptif fenomena. Penelitian ini menggunakan metode lapangan yang menyajikan data dan fenomena-fenomena yag berdasarkan data empiris yang ditemukaan oleh peneliti. Sumber data dalam penelitian ini adalah data bahasa lisan yang berupa tuturan-tuturan dalam berbagai peristiwa bahasa Muna yang bersumber dari penutur asli bahasa muna. Teknik yang digunakan untuk mengumpulkan data dalam penelitian ini adalah teknik rekam dan teknik catat. Teknik analisis data menggunakan pendekatan pragmatik, pendekatan pragmatik digunakan sebagai upaya interpretasi makna dengan penafsiran yang tepat berdasarkan konteks yang ada dalam deiksis persona pada bahasa daerah Muna. Berdasarkan pembahasan hasil penelitian, dapat disimpulakan sesuai dengan pronomina persona maka deiksis persona dalam bahasa Muna terdiri dari tiga bentuk yaitu Deiksis persona pertama terbagi dua yaitu persona pertama tunggal yang terdiri dari morfem bebas dan morfem terikat dan persona pertama jamak yang terdiri dari morfem bebas serta morfem terikat. Deiksis persona kedua terdiri dari deiksis persona kedua tunggal yang terbagi dua yaitu persona kedua tunggal yang terdiri dari morfem bebas dan morfem terikat dan persona kedua jamak yang terdiri dari morfem bebas serta morfem terikat Deiksis persona ketiga terbagi dua yaitu deiksis persona ketiga tunggal yang terdiri dari morfem bebas morfem terikatnya dan persona ketiga jamak yang terdiri dari morfem bebas serta morfem teerikat Deiksis persona bahasa Muna dalam situasi tertentu bisa digantikan oleh deiksis tempat.
\end{abstract}

Kata kunci : bentuk; deiksis; makna

537 | Jurnal BASTRA (Bahasa dan Sastra), Vol. 4 No.4, Edisi Oktober 2019/e-ISSN: 2503-3875/ http://ojs.uho.ac.id/index.php/BASTRA 


\begin{abstract}
The purpose of this study is to describe the form and meaning of the word deiksis persona in the Muna language. This type of research is a qualitative descriptive. Qualitative research is always descriptive, means the data analyzed and the analysis result is a descriptive phenomenon. The research uses a field method that presents data and phenomena based on empirical data that is being found by researchers. The data sources in this study are spoken language data in the form of speech in various Muna language events sourced from native speakers of the Muna language. The techniques used to gather data in this research are the recording techniques and note taking techniques. Data analysis techniques use a pragmatic approach. A pragmatic approach is used as an attempt to interpret meaning with proper interpretation based on the context present in the deiksis of the persona in the Muna region language. Based on the discussion of the research, can be stored in accordance with Persona Hailee then the deiksis persona in Muna language consists of three forms that the first persona divided into two is the first single persona consisting of free morpheme and morpheme bound and the first plural persona consisting of free morpheme as well as morpheme bound. The second Persona deiksis consists of a single second persona that is divided into two, a single persona consisting of free morpheme and bonded morpheme and both plural persona consisting of free morpheme as well as morpheme bound by the third persona. Divided into two is a single third persona, consisting of a morpheme free morpheme and a plural third persona consisting of free morpheme as well as bounded morpheme deiksis Muna language persona in certain situations can be replaced by the Deiksis place .
\end{abstract}

\title{
Keywords: deiksis; form; meaning
}

538 | Jurnal BASTRA (Bahasa dan Sastra), Vol. 4 No.4, Edisi Oktober 2019/e-ISSN: 2503-3875/ http://ojs.uho.ac.id/index.php/BASTRA 


\section{PENDAhULUAN}

Bahasa merupakan alat komunikasi yang paling utama. Karena bahasa itu tidak dapat dipisahkan dari kehidupan manusia sebagai alat interaksi dengan yang lainnya. Komunikasi akan berjalan lancar apabila sasaran bahasa yang digunakan tepat, artinya bahasa itu dipergunakan sesuai dengan situasi dan kondisi penutur dan sifat pertuturan itu dilaksanakan. Hal ini, sangat bergantung pada faktor-faktor penentu dalam tindak bahasa atau tindak komunikasi, yaitu lawan bicara, tujuan pembicara, masalah yang dibicarakan,dan situasi. Penggunaan bahasa seperti ini merupakan kajian pragmatik.

Pagmatik adalah studi tentang makna yang disampaikan oleh penutur (atau penulis) dan ditafsirkan oleh pendengar (atau pembaca). Sebagai akibatnya studi ini lebih banyak berhubungan dengan analisis tentang apa yang dimaksudkan dengan tuturantuturannya daripada dengan makna terpisah dari kata atau frasa yang digunakan dalam tuturan itu sendiri. Pragmatik adalah studi tentang maksud penutur.

Pendekatan pragmatik ini juga perlu menyelediki bagaimana cara pendengar dapat menyimpulkan tentang apa yang dituturkan agar dapat sampai pada suatu interpretasi makna yang dimaksudkan oleh penutur. Tipe studi ini menggali betapa banyak yang disampaikan. Kita boleh mengatakan bahwa studi ini adalah studi pencarian makna yang tersamar. Pragmatik adalah studi tentang bagaimana agar lebih banyak yang disampaikan daripada yang dituturkan.

Setiap bahasa tidak akan terlepas dari pemakaian deiksis. Karena deiksis selalu muncul dalam konteks ujaran. Begitu juga dalam bahasa daerah bagi masyarakat penuturnya. Salah satunya bahasa daerah Muna.

Bahasa Muna adalah salah satu bahasa daerah yang ada di Sulawesi tenggara yang dipergunakan oleh masyarakat penuturnya dan merupakan salah satu bahasa daerah yang mempunyai penutur cukup besar dan luas. Bahasa Muna merupakan bahasa yang hidup dan berkembang, yang digunakan oleh kelompok suku Muna sebagai bahasa pergaulan. Secara umum, bahasa Muna bagi masyarakat penuturnya disamping berfungsi sebagai bahasa pengantar juga berfungsi sebagai alat pendukung kebudayaan daerah bagi masyarakat penuturnya.

Dalam penelitiaian ini lebih fokuskan pada deiksis persona. Dengan menyebut penutur ('saya') dan lawan tutur ('kamu'). Kesederhanaan bentuk-bentuk ini menyembunyikan kerumitan pemakainya. Dipilihnya bahasa daerah Muna sebagai objek penelitian ini karena dalam bahasa daerah Muna tersebut terdapat banyak deiksis yang menarik dikaji dalam suatu kajian pragmatik. Salah satu contohnya

La Puli : Inodi akala we daowa indewi, ane ihintu?

Saya pergi ke pasar kemarin, kalau kamu ?

Wa Nunung : Inodi akala we lambuno fokoamauku.

Saya pergi ke rumah pamanku.

Kata 'inodi' di atas sebagai kata ganti dari dua orang. Kata 'inodi' yang pertama adalah kata ganti dari La Puli. Sementara itu, kata 'inodi' yang kedua adalah kata ganti Wa Nunung. Dari contoh diatas, tampak kata 'inodi' memiliki referen yang berpindahpindah sesuai dengan konteks pembicaraan serta situasi berbahasa.

539 | Jurnal BASTRA (Bahasa dan Sastra), Vol. 4 No.4, Edisi Oktober 2019/e-ISSN: 2503-3875/ http://ojs.uho.ac.id/index.php/BASTRA 
Berdasarkan uraian sebelumnya, dapat dirumuskan masalah dalam penelitian ini adalah "Bagaimanakah bentuk-bentuk deiksis persona dalam bahasa muna ?"

Tujuan yang ingin dicapai dalam penelitian ini adalah untuk mendeskripsikan bentuk-bentuk deiksis persona dalam bahasa Muna.

Penelitian ini diharapkan dapat bermanfaat sebagai berikut :

1. Menambah pengetahuan masyarakat bahasa tentang deiksis persona dalam bahasa daerah Muna.

2. Menjadi perbandingan kepada peneliti-peneliti lainnya yang akan menganalisis hal yang sama dalam bidang linguistik, khususnya yang ingin meneliti tentang deiksis persona.

Penelitian ini hanya dibatasi pada salah satu jenis deiksis yaitu deiskis persona saja.

Untuk menghindari salah penafsiran dalam penelitian ini perlu diberikan penjelasan terhadap istilah yang ada dalam judul penelitian.

1. Deiksis adalah kata yang referennya berpindah-pindah atau berganti-gnati, tergantung pada siapa yang menjadi si pembicara dan tergantung pada saat dan tempat dituturkannya kata itu (Purwo, 1984: 1).

2. Deiksis persona adalah deiksis yang menerapkan tiga pembagian dasar yaitu pronomina pertama, pronomina kedua, pronomina ketiga (Yule, 2006: 15).

3. Bahasa Muna merupakan bahasa yang hidup dan berkembang, yang digunakan oleh kelompok suku Muna sebagai bahasa pergaulan. Secara umum, bahasa Muna bagi masyarakat penuturnya disamping berfungsi sebagai bahasa pengantar juga berfungsi sebagai alat pendukung kebudayaan daerah bagi masyarakat penuturnya.

4. Pragmatik adalah studi tentang hubungan tuturan dengan pembicara, konteks, makna yang dikomunikasikan, dan ekspresi menurut jarak sosial.

\section{METODE DAN TEKNIK PENELITIAN}

Jenis dan MetodePenelitian

Jenis penelitian ini adalah deskriptif kualitatif. Penelitian kualitatif selalu bersifat deskriptif, artinya data yang dianalisis dan hasil analisisnya berbentuk deskriptif fenomena. Metode kualitatif memberikan perhatian terhadap data alamiah, data dalam hubungannya dengan konteks keberadaannya.

Metode Penelitian

Penelitian ini menggunakan metode lapangan yang menyajikan data dan fenomena-fenomena yang berdasarkan data empiris yang ditemukan oleh peneliti. Selain itu, peneliti juga akan menyajikan data yang diperoleh dari sumber data yang objektif. Dikatakan penelitian lapangan karena data dalam peneltian ini berupa data lisan dari beberapa informan untuk mengumpulkan dan mendapatkan data yang diperlukan peneliti dengan cara menelaah dan menganalisis deiksis dalam bahasa Muna.

Data dan Sumber Data

Data yang digunakan dalam penelitian ini adalah data bahasa lisan yang berupa tuturantuturan dalam berbagai peristiwa bahasa Muna yang bersumber dari penutur asli bahasa Muna di Desa Kontunaga, kecamatan kontunaga kabupaten Muna. Berdasarkan hal itu, maka

\section{0 | Jurnal BASTRA (Bahasa dan Sastra), Vol. 4 No.4, Edisi Oktober 2019/e-ISSN: 2503-3875/ http://ojs.uho.ac.id/index.php/BASTRA}


dalam penelitian ini ditetapkan beberapa orang sebagai informan. kriteria pemilhan (1) penutur asli bahasa Muna, (2) sudah dewasa (berkisar (18-60 tahun), (3)menngunakan bahasa Muna sebagai bahasa utama, (4) Mengerti bahasa Indonesia, (5) berpendidikan minimal SD/Sederajat.

\section{Metode dan Teknik Pengumpulan Data}

Untuk mengumpulkan data dari penelitian ini adalah digunakan metode simak dan metode cakap. Metode simak yaitu metode yang digunakan untuk memperoleh data dengan cara menyimak setiap pembicaraan informan. Metode cakap yaitu metode yang digunakan untuk memperoleh data lisan dengan cara mengadakan kontak langsung dengan informan. Kontak langsung yang dimaksud adalah kontak langsung secara verbal.

Teknik Pengumpulan Data

Sejalan dengan metode di atas, maka teknik yang digunakan dalam pengumpulan data adalah teknik rekam dan teknik catat. Selain itu, setelah data terkumpul, peneliti juga menggunakan teknik introspeksi melalui teknik elisitasi yaitu mengoreksi sekumpulan aktivitas yang ditunjukkan melalui sistem komunikasi, peneliti juga menggunakan teknik trianggulasi yakni peneliti dapat membuat data sendiri, kemudian data tersebut diverifikasi kepada informan yang telah memenuhi kritera yang telah ditentukan. Verifikasi data tersebut menyangkut struktur kalimat. Ketiga teknik ini (teknik intropeksi, teknik elisitasi, dan trianggulasi), dipergunakan karena peneliti juga adalah penutur asli bahasa Muna. Teknik rekam digunakan dengan pertimbangan bahwa data yang diteliti berupa data lisan. Selain teknik rekam, digunakan pula teknik catat melalui media yang disiapkan peneliti yakni smartphone (telephone pintar).
Instrumen Penelitian

Penelitian ini menjadikan peneliti sebagai instrument utama dalam pengumpulan data karena peneliti sebagai penutur asli bahasa Muna. Hal ini, sesuai dengan pendapat Aminudin dalam (Nursila, 2016: 34) bahwa dalam penelitian kualitatif, peneliti sendiri merupakan instrumen kunci, baik dalam pengumpulan data maupun analisis data, walaupun manusia bersifat subjektif, tetapi manusia sebagai instrumen utama dapat menghasilkan data yang reliabilitasnya hampir sama dengan data yang dihasilkan instrumen yang dibuat secara lebih objektif.

Selain peneliti yang menjadi instrumen utama, dalam peneliti ini menggunakan juga instrumen tambahan. Instrumen tambahan yang dimaksud adalah alat perekam yakni smartphone (telepon pintar) dan kartu data sesuai dengan teknik yang digunakan yaitu teknik rekam dan teknik catat.

\section{Metode dan Teknik Analisis Data}

Dalam menganalisis data, penelitian ini menggunakan metode deskriptif yakni menguaraikan dan menginterpretasikan data berdasarkan apa yang ditemukan dalam penelitian, seperti interpretasi data bahasa lisan yang mengandung deiksis persona bahasa Muna.

\section{Teknik Analsis Data}

Analisis data dilakukan dengan menggunakan pendekatan pragmatik. Pendekatan pragmatik digunakan sebagai upaya interpretasi makna dengan penafsiran yang tepat berdasarkan konteks yang ada dalam deiksis persona pada bahasa daerah Muna.

\section{1 | Jurnal BASTRA (Bahasa dan Sastra), Vol. 4 No.4, Edisi Oktober 2019/e-ISSN: 2503-3875/ http://ojs.uho.ac.id/index.php/BASTRA}


Analisis data dilakukan melalui tahapan-tahapan, sebagai berikut:

1. Identifikasi data, maksudnya data deiksis persona bahasa Muna yang sudah ditemukan dalam penelitian diberi kode sesuai permasalahan penelitian.

2. Klasifikasi data adalah mengklasifikasikan data deiksis persona bahasa Muna yang telah diklasifikasikan dengan menentukan acuan-acuan deiksis persona yang berpindah-pindah atau bergantiganti.

3. Interpretasi, maksudnya suatu proses penafsiran data deiksis persona bahasa Muna yang telah diklasifikasikan dengan menentukan acuan-acuan deiksis persona yang berpindah-pindah atau berganti-ganti.

4. Deskripsi data, maksudnya data yang sudah diklasifikasikan dan diinterpretasikan kemudian dideskripsikan dengan menggunakan pendekatan deksriptif yaitu dengan membandingkan deiksis persona bahasa Muna dengan deiksis persona bahasa Indonesia (Purwo, 1984: 16), kemudian dirumuskanlah sebuah simpulan setiap bentukbentuk deiksis persona bahasa Muna.

\section{HASIL DAN PEMBAHASAN}

Sebelum membahas tentang deiksis persona bahasa Muna, dalam Bab IV ini akan dipaparkan secara ringkas tentang pronomina bahasa Muna karena deiksis persona dalam pemakaiannya menerapkan pronomina persona.

\subsection{Pronomina Persona Bahasa Muna}

Seperti bahasa Indonesia, bahasa Muna juga memiliki pronomina persona yang terdiri atas tiga bentuk yaitu (1) pronomina persona pertama, (2) pronomina persona kedua, dan (3) pronomina persona ketiga. Ketiga pronomina tersebut terbagi lagi menajdi dua, yaitu pronomina yang bisa berdiri sendiri sebagai morfem bebas dan pronomina yang tidak bisa berdiri sendiri atau pronomina yang selalu dibubuhkan pada bentuk dasar sebagai morfem terikat

Persona Tunggal Jamak

$$
\text { Bebas Terikat Bebas Terikat }
$$

Pertama Inodi 'saya' a-,ae-,ao,-kanau, ku Intaidi,

Intaidimu 'kita sekalian'

Insaidi Da-, dae-, dao-,do,nto

Da-Vmu, dae-Vmu, do-Vmu, ntoomu

Tae-, tao-,V-e, -mani, -kasami

Kedua

Ihintu 'kamu'

o-, ome-, omo-, -angko ,ko,mu

Ihintuumu 'kalian semua'

o- Vmu, ome- Vmu, omo- Vmu, -angkoomu, koomu,-Vmu.

Ketiga Anoa 'dia' Na-, nae-, ne-, nao-, no-,-ane, -e, -on Andoa 'mereka' Da-, dae-, de-, dao-, do, -anda, -da, -ndo

(Fatinah, 2014:137-145)

\subsection{Bentuk-bentuk Deiksis Persona}

Berdasarkan bentuk-bentuk pronomina, dapat diketahui bentuk-bentuk deiksis persona bahasa Muna. Berikut ini akan diuraikan bentuk-bentuk deiksis persona bahasa Muna yang disertai dengan data dalam kalimat. 


\subsubsection{Deiksis Persona Pertama}

Dalam bahasa Muna, dikenal pronomina persona pertama tunggal adalah inodi 'saya'. Bentuk inodi 'saya', biasanya digunakan dalam berbagai bentuk ujaran dan digunakan pembicara untuk menunjukkan dirinya sendiri.

Data :

(1) Mita : Inodi akala we Kandari. Ane ihintu ga okala nehamai ?

"Saya saya pergi ke

Kendari. Kalau kamu kah kamu pergi kemana?"

'Saya pergi ke Kendari. Kalau kamu pergi kemana?'

(2) Aris : Ane inodi miina ekala-kala we lambu kaawu

"Kalau saya tidak kemana-mana di rumah saja." rumah saja.'

'Kalau saya tidak kemana-mana di

Konteks : Aris dan Mita adalah teman sekelas. Mereka bertemu kembali di Sekolah setelah libur semester dan menceritakan kemana mereka pergi saat liburan.

Hikma : Omeafa ?

"Kamu sedang apa ?"

'Kamu sedang apa?'

(4) Fina : Inodi egau kenta. Ingka afetingke oguma mo ?

"Saya memasak ikan. Saya dengar kamu mau menikah?"
'Saya memasak Ikan. Saya dengar kamu akan menikah ?'

(5) Hikma :Umbe, amai amoratoko pada, Inodi aguma bhe poraiku.

"Iya, saya kesini ingin menyampaikan, saya akan menikah dengan pacarku."

Konteks : Hikma berkunjung ke rumah sahabatnya yang bernama Fina untuk memberitahukan perihal pernikahannya.

Kata inodi 'saya' pada data (1), (2), (4), dan (5) mempunyai referen atau rujukan yang berbeda jika dilihat dari siapa yang berbicara . Pada data pertama (1) kata inodi 'saya' mengacu pada Mita yang pergi ke Kendari, pada data kedua (2) mengacu pada Aris yang tidak kemana-mana dan hanya di rumah , data ketiga (4) mengacu pada Fina yang memasak ikan, sedangkan data keempat (5) mengacu pasda Hikma yang akan menikah dengan kekasihnya. Pronomina persona pertama bahasa Muna inodi 'saya' bersifat deiksis karena referennya berpindah dan berganti sesuai konteks wacananya.

\subsubsection{Deiksis Persona Kedua}

Dalam Bahasa Muna pronomina persona kedua ada dua, yaitu ihintu 'kamu' atau “engkau' dan ihintuumu atau ihintoomu 'kamu sekalian'.

Pronomina persona ihintu 'kamu' atau 'engkau' merupakan bentuk pronomina yang bisa berdiri sendiri sebagai morfem bebas. Ihintu bisa berubah menjadi omo-, ome-, o-, gho, o- v-e, dan -mu sebagai bentuk dasar.

Pronomina persona kedua tunggal bahasa Muna mempunyai wujud, yakni ihintu 'kamu'. Bentuk pronomina persona kedua tunggal ihintu 'kamu'.

Data :

543 | Jurnal BASTRA (Bahasa dan Sastra), Vol. 4 No.4, Edisi Oktober 2019/e-ISSN: 2503-3875/ http://ojs.uho.ac.id/index.php/BASTRA 
(6) Awan : Ihintu wa Kiki to, sabhangkaku sekalasi kamponahomo?

"Kamu wa Kiki to, temanku sekelas dulu?"

'Kamu wa Kiki to, teman sekelasku dulu?'

(7) Kiki : Umbe, ihintu dua miinamo otumandai kanau.

"Iya, kamu juga tidak lagi mengenal saya."

'Iya, kamu juga sudah tidak kenal saya.'

(8) Awan : Ihintu kapasolemu.

"Kamu cantik kamu."

'Kamu cantik.'

(9) Kiki : Kaghohimu lagi kune ihintu itu.

'Bohongmu lagi kamu itu.'

'Bohong lagi kamu itu.'

(10) Awan : Ihintu sokumalano we Kandari.

"Kamu yang akan pergi ke Kendari."

'Kamu yang akan ke Kendari.'

(11) Kiki : Minahi ato kaawu pisaku.

"Tidak antar hanya sepupuku."

'Tidak saya hanya mengantar sepupuku.'

Konteks : Awan dan Kiki adalah teman lama mereka tidak sengaja bertemu di pelabuhan.

Pada data (6) kata ganti ihintu merujuk pada seorang sasaran tutur yang merupakan teman sekelas Awan, pada data (7) merujuk pada seorang sasaran tutur yang merupakan orang yang tidak lagi mengenal
Awan, pada data (8) merujuk pada seorang sasaran tutur yang sudah cantik, pada data (9) merujuk pada seseorang sasaran tutur yang merupakan pembohong, sedangkan pada data (10) merujuk pada seorang sasaran tutur yang akan pergi ke Kendari. Dari data (6) sampai (11) dapat dilihat ciri kedektisan pronomina ihintu 'kamu' pada masing-masing data tersebut.

\subsubsection{Deiksis Persona Ketiga}

Pronomina persona ketiga tunggal bahasa Muna terdiri atas anoa 'dia' menunjuk pada persona di luar percakapan. Bentuk kata ganti persona ketiga tunggal anoa 'dia' dapat berfungsi sebagai subjek dan objek.

Data :

(12) Rani : Nokala nehamai wa Fina ?

"Dia pergi dimanakah wa Fina ?"

'Pergi kemanakah wa Fina?'

(13) Ibunya Fina : Wa Fina nokala we galu. Anoa nokala bhe aino.

"Wa Fina dia pergi ke kebun. Dia dia pergi dengan adiknya."

'Wa Fina pergi ke kebun. Dia pergi bersama adiknya.'

Konteks : Rani adalah teman Fina, dia pergi berkunjung ke rumah Fina namun Fina tidak ada dia pergi ke kebun bersama adiknya.

(14) Cia : Noafa miina neparasogho inamu?

"Dia kenapa tidak dia menjual ibumu ?"

'Kenapa ibumu tidak berjualan di pasar ?' 
(15) Sari : Inaku miina naoala kadaowano, rampahano no bhari marasano kambulu peda anoa.

"Ibuku tidak laku jualannya, karenanya dia banyak yang menjual sayur seperti dia."

'Ibuku tidak laku jualannya, karena banyak yang menjual sayur seperti dia.'

(16) Cia : Gaara, akapihie pada anini we daowa tamaka mina amorae.

"Begitu, saya mencarinya tadi di pasar tetapi tidak saya lihat."

'Begitu, saya mencarinya tadi di pasar tapi saya tidak ketemu.'

Konteks : Cia bertanya kepada Sari tentang ibu Sari yang sudah tidak berdagang dipasar.

(17) Idris : Nokala nehami gara la Puli ?

"Dia pergi kemanakah la Puli ?"

'Pergi kemanakah la Puli ?'

(18) Opin : La Puli nokala we karuku, rampahano anoa naghumondo katandono.

"La Puli dia pergi ke hutan, karenanya dia dia ingin melihat jeratnya."

'La Puli pergi ke hutan, karena dia akan menengok jeratnya.'

(19) Idris : Noafa dua miina nobhasi kanau bhela.

"Dia kenapa juga tidak dia panggil saya."

'Kenapa juga dia tidak mengajak saya.'

(20) Opin :Pabheangkomo itu pada.

"Tidak tau juga itu."
'Tidak tau juga.'

Konteks : Idris yang berkunjung ke rumah sahabatnya La Puli ternyata La Puli pergi ke hutan, kakak La Puli yang bernama Opin memberitahukan itu kepada Idris.

Pada data (13) kata ganti anoa 'dia' merujuk pada Wa Fina yang pergi ke kebun, pada data (15) merujuk pada inaku yang tidak laku jualannya, sedangkan data (18) merujuk pada La Puli yang pergi ke hutan untuk menengok jeratnya. Perpindahan atau pergeseran rujukan ini menunjukkan bahwa kata ganti anoa merupakan kata yang bersifat deiksis

\subsection{Pemarkah Deiksis Persona yang Bukan} Pronomina

Dalam bahasa Muna dapat ditemukan deiksis persona yang bisa menjadi deiksis tempat.

Data :

(21) Imam : Ingka daebasamo ini ?

"Imam : kitamulaimi ini ?"

'Imam : Kita akan mulai ini ?'

(22) Tuan Rumah : Terserahmo naitu.

"Tuan Rumah : Terserahmi disitu."

'Tuan Rumah : Terserah disitu.'

Konteks : Data (120) dan (121) terjadi ercakapan ketika Imam menanyakan acara akan segera dimulai pada Tuan rumah.

(23) Ustad : Basa kaetamo dhoa.

"Ustad : Baca kitami doa."

'Ustad : Bacakan kita doa.'

(24) Jama'ah : Naitumo.

“Jama'ah : Di situmi." 
'Jama'ah : Di situ saja.

Konteks : Data (21) dan (24) terjadi percakapan ketika Ustad mempersilahkan (seorang jama'ah) untuk membaca do'a penutup setelah selesai mengerjakan shalat Jum'at.

Pada data, kata naitu 'di situ' merupakan deiksis tempat yang menggantikan deiksis persona. Karena kata naitu 'di situ' tidak menunjukkan suatu tempat tetapi menunjuk pada deiksis persona (Imam). Hal ini lazim terjadi dalam bahasa Muna terutama dalam peristiwa acara adat. Setelah ditelusuri, ternyata perubahan deiksis tempat menjadi deiksis persona merupakan bentuk honorific (penghormatan) kepada seseorang.

\section{PENUTUP}

Merujuk pada rumusan masalah yang telah dibahas dalam Bab IV, sehingga simpulan yang diperoleh dalam penelitian ini adalah

a. Sesuai dengan pronomina persona maka deiksis persona dalam bahasa Muna terdiri dari tiga bentuk yaitu deiksis persona pertama, deiksis persona kedua, dan deiksis persona ketiga.

b. Deiksis persona pertama terbagi dua yaitu persona pertama tunggal yang terdiri dari morfem bebas (inodi/indodi/idi 'saya') dan morfem terikat (ae-,a-,ao-,-ku, dan -kanau 'saya') dan persona pertama jamak yang terdiri dari morfem bebas (intaidi 'kita berdua', intaidi:mu 'kita semua') serta morfem terikat (dae-,da-,dao-,da-e,dan -nto 'kita berdua', tae-, tao-, ta-, ta- ... -e. -mani, dan kasami 'kita')

c. Deiksis persona kedua terdiri dari deiksis persona kedua tunggal yang terbagi dua yaitu persona kedua tungal yang terdiri dari morfem bebas ( ihintu 'kamu' atau 'engkau') dan morfem terikat (omo-Ome-, o-, -gho, o- ... e. dan mu- 'kamu' atau 'engkau' ) dan persona kedua jamak yang terdiri dari morfem bebas (ihintuumu atau ihintoomu 'kamu sekalian') serta morfem terikat (omo... -mu, ome- ... -mu, o- ... -e:mu, -gho:mu, dan -omu 'kalian semua).

d. Deiksis persona ketiga terbagi dua yaitu deiksis persona ketiga tunggal yang terdiri dari morfem bebas (anoa 'ia' atau 'dia') morfem terikatnya (nae-, ne-, -no, -ane, dan no- ... -e 'ia/dia') dan persona ketiga jamak yang terdiri dari morfem bebas (andoa 'mereka') serta morfem teerikat (dae-, do-, de, -nda, -ndo, dando- ... -e 'mereka')

e. Deiksis persona bahasa Muna dalam situasi tertentu bisa digantikan oleh deiksis tempat.

Saran

1. Bagi peneliti selanjutnya diharapkan untuk mengkaji lebih dalam lagi tentang deiksis bahasa Muna terutama yang belum dikaji dalam penelitian ini seperti pada aspek kearifan lokal dan aspek lainnya.

2. Pemahaman terhadap deiksis persona perlu ditingkatkan karena dapat membimbing kita untuk selalu menjunjung nilai-nilai tata krama sosial terutama dalam bentuk kesantunan berbahasa. 


\section{DAFTAR PUSTAKA}

Fatinah, Sitti. 2014. Pronomina Persona dalam Bahasa Muna. Gramatika, Vol. II, No. 2, Juni- Desember 2014: 137.

Kridalaksan, Harimurti. 1993. Kamus Linguistik. Jakarta: Gramedia Pustaka Utama.

Purwo, Bambang Kaswanti. 1984. Deiksis dalam Bahasa Indonesia. Jakarta: Balai Pustaka.

Putrayasa, Ida Bagus. 2014. Pragmatik. Yogyakarta: Graha Ilmu.

Rahardi, Kunjana. 2005. Pragmatik Kesantunan Imperatif Bahasa Indonesia. Jakarta: Gelora Aksara Pratama.

Sahirudin. 2013. Deiksis Persona Bahasa

Kambowa. Skripsi. Kendari : Universitas Halu Oleo.

Yule, George. 2014. Pragmatik. Yogyakarta. Pustaka Pelajar. 